\title{
Study of the efficacy of Shardul Ghanvati in the management of Udara - Jatodakawastha
}

\author{
ResearchArticle
}

\section{Sudarshankumar R Mehta ${ }^{1^{*}}$, Londhe PD $^{2}$}

1. PG Scholar, 2. Associate Professor, Department of Kayachikitsa, SCM Aryangla Vaidyak Mahavidyalaya, Satara

\begin{abstract}
The clinical research study was carried out on 30 pateints of Udara-Jatodakawastha to evaluate the efficacy of Shardul Ghanavati in the management of Udara-Jatodakawstha, The study was conducted at department of Kayachikitsa, Aryangla Ayurvedic College and Hospital Satara, Maharashtra. For assessment of result patient was investigated before after for Hemogram, Liver function test \& USG Abdomen. Clinical features like Abdominal girth, change in weight, Breathlessness, yellowness of sclera, pedal edema and loss of appetite were assessment criteria for analysis of result.The study reveals that Shardul Ghanavati has significant role in management of Udara-Jatodakawastha, The total efficacy of treatment was found $\mathbf{5 9 . 3 7 \%}$ in subjective criteria, and significant result found in objective criteria (weight \& girth measurement), as well as supplementary criteria in period of two months.In sitting position $11.97 \%$ reduction in abdominal girth, In supine position $11.34 \%$ reduction in abdominal girth \& mean score reduction in weight $12.48 \%$ take place. Also it gives immediate relief to patient by doing "Virechana" karma, which is pradhan chikitsa of Udara-Jatodakawastha.
\end{abstract}

Keywords: Udar-Jatodakawastha, Shardul Ghanavati, Virechana

\section{Introduction}

Now a days there is tremendous change in life style of people taking junk food, aerated cold drinks, adulterated food materials excessive consumptions of alcoholic beverages gives excess load on liver, Which leads to produce many liver disorders. These liver disorders may results into a disease Called ascites. Also infections like Tuberculosis, Hypoproteinemia due to malnutrition leads to develop ascites, it is common disorder in underdeveloped and developing countries. Ascites is gastroenterological term in which there is accumulation of fluid in peritoneal cavity. Presence of ascites can portent significant medical problems like Renal failure, Hepatorenal shut down, Bacterial peritonitis etc. Ascites is a major complication of cirrhosis, it is associated with $50 \%$ mortality over two years and signifies the need for Liver Transplantation. The majority $(75 \%)$ of patients who present with ascites have underlying cirrhosis, with remainder being due to Malignancy $(10 \%)$, Heart failure 3\%, Tuberculosis $2 \%$, Pancreatitis $1 \%$ \& other rare causes(1). Since so many years lots of patient of Udara-Jatodakawstha were treated well in our hospital on IPD and OPD basis these patient were responded well to Ayurvedic herbal preparation so I decided to work on this disease.

*Corresponding Author:

\section{Sudarshankumar R Mehta}

PG Scholar, Department of Kayachikitsa,

SCM Aryangla Vaidyaka Mahavidyalaya,

Satara. Maharashtra

Mobile No.: +91- 7350236998

E-mail: tejpalmehta511@gmail.com
Udara-Jatodakawstha is parallel term to ascites, In Ayurveda it is described in all samhitas, In Ayurvedic literature Many herbs and herbal combinations are described for Udara-Jatodakawastha \& it is a clinical entity which has been included under eight dreaded disease (Ashtomahagad) by Acharya Charaka The rational and important treatment of this disease mentioned by Charaka is Agnisandhukshan, Virechan and Pathyapathya (i.e to avoid hetusevan). So the diet for Udara will be laghu \& deepana helps in agnivardhana in the form of Yusha, Mamsarasa which also helps to reduce strotorodha in Udara. Godugdh has prime importance in treatment as well as in pathyapathya chikitsa (2).

Charaka had described both medical and surgical management of Udara-Jatodakawastha, Charaka and Vagbhata had mentioned various virechaka drugs and their kalpas in the management of UdaraJatodakawastha, still medical management of UdaraJatodakawastha is a challenge to medical field. The objective of this study was to establish and reassess the effect of Shardul Ghanavati mentioned by, Ashtanghirdaya Chikitsasthan 14/36 In the management of Udara-Jatodakawastha.

Hypothesis (3):

Null hypothesis $\left(\mathrm{H}_{0}\right)$ :

Shardul Ghanavati is not effective in the management of Udara- jatoakawastha

Alternate hypothesis $\left(\mathrm{H}_{1}\right)$ :

Shardul Ghanavati is effective in the management of Udara-jatodakawstha. 
Aims and objectives

1) To study the etiopathology and prognosis of Udarajatodakawastha

2) To Study the efficacy of Shardul Ghanavati in the management of Udara-Jatodakawastha.

3) To study the standardization of ingredients of Shardul Ghanavati.

4) To study the mode of action of Shardul Ghanavati

5) To study adverse effect of Shardul Ghanavati if any.
Materials and methods

Materials:

1. Patients:

Total 30 patients of Udara-Jatodakawstha from OPD and IPD unit of Dr. M. N. Agashe, hospital, Satara were selected irrespective of their religion and sex.

\section{Drug : Shardul Ghanavati}

For the present study Shardul Ghanavati was used for the management of Udara - Jatodakawastha, the details of formulation and method of preparation are as follows.

Table no- 1 :

Details of Shardul Ghanavati (4)

\begin{tabular}{|l|l|l|l|l|}
\hline Sr. no & Drug name & Latin/English name & Part used & Qantity \\
\hline 1 & Hingu & Ferula asafoetida L. & Niryas (Gum resin) & 1 part \\
\hline 2 & Vacha & Acorus calamus L. & Rhizome (Bhumik-kand) & 2 part \\
\hline 3 & Bidlawan & NACL & & 3 part \\
\hline 4 & Shunthi & Zingiber officinalis Roscoe. & Rhizome & 4 part \\
\hline 5 & Ajagi (Jire ) & Cuminum cyminum L. & Seed & 5 part \\
\hline 6 & Haritaki & Terminalia chebula Retz. & Fruit & 6 part \\
\hline 7 & Pushkarmul & Inula racemosa CB Clarke. & Root & 7 part \\
\hline 8 & Kushtha & Sassurea lappa (Decne.) Sch.Bip. & Root & 8 part \\
\hline 9 & Nishotar & Operculina turpethum (L.) Silva Manso & Root & part \\
\hline 10 & Danti & Baliospermum montanum (Willd.) Muell. & Root & 10 Part \\
\hline
\end{tabular}

\section{Criteria for diagnosis:}

Patients having abdominal distention, positive fluid thrill and shifting dullness were selected The inclusion and exclusion criteria used for the patients were as follows:

\section{A) Inclusion criteria:}

- Kukshi aadhman

- Aatop

- Padshopha

- Mandagni

- Shalshangandatwa

- Karshya

- Patient having age between 20 to 70 years

B) Exclusion criteria:-

- Chhidrodar

- Baddhrodar

- Cardiac failure

- Renal failure

- Malignancies

- Hemorrhagic disorders

- HIV \& HBsAg infection

- Altered consciousness

- Pancreatic ascites
Assessment criteria:

1. Gradation of Ascites

$\begin{array}{ll}\begin{array}{l}\text { Grade } \\ \text { (NS) }\end{array} & \begin{array}{l}\text { Severity of symptom } \\ \text { (Udara-jatodakawastha) }\end{array} \\ 0 & \text { No fluid } \\ 1 & \text { Mild } \\ 2 & \text { Moderate } \\ 3 & \text { Gross }\end{array}$

2. Abdominal girth

Grade Percentage reduction in abdominal girth

$0 \quad>15 \%$

$1 \quad 11 \%-15 \%$

$2 \quad 6 \%-10 \%$

$3 \quad 1 \%-5 \%$

$4 \quad$ No change

\section{Mandagni}

\section{Grade Hunger after taking food in hours}

$0 \quad$ Patient feeling complete digestion \& hunger after 3 hour of taking meal

1 Patient feeling hunger after 4-7 hour of taking meal

2 Patient feeling hunger after 8-11 hour of taking meal

3 No feeling of hunger even after 12 hour of taking meal 


\section{Pedal edema}

Grade

0

Pedal edema after pressing normalizes within

No edema

$1 \quad 1-3$ second

$2 \quad 4-6$ second

3 7-9 second

$4 \quad$ More than 10 second

\section{Breathlessness}

Grade

0 None

$1 \quad$ Mild

$2 \quad$ Moderate

$3 \quad$ Severe

$4 \quad$ Very

Severe

\section{Breathlessness}

Not trouble by shortness of breath on level or uphill

Troubled by shortness of breath on level or uphill

Walk slower than person of same age

Stop after walking 100 yard or after few minute on level ground

Too breathless to leave the house breathless on dressing or undressing

Groups of Management:-

All the selected patients were allocated to single group which was treated by Shardul Ghanavati.
Table no - 2 : Showing the details of drug administration are as follows.

\begin{tabular}{|l|l|}
\hline Drug & SHARDUL GHANAVATI \\
\hline Form of drug & Ghanavati (Tablet) \\
\hline Dose & 1500 mg (3 tablets each of 500 mg) \\
\hline Anupana & Luke warm water (Koshnajala) \\
\hline Sevena kala & $\begin{array}{l}\text { Empty stomach early in the } \\
\text { morning (A bhakta i.e.Pratahkal) }\end{array}$ \\
\hline Duration & 2 Month \\
\hline Follow up & Weekly \\
\hline Diet & Diet mention as per Samhita \\
\hline Vihara & $\begin{array}{l}\text { Avoid diwaswap, Chankraman and } \\
\text { exercise }\end{array}$ \\
\hline
\end{tabular}

Observations and results

Table no.3: Showing Distribution of 30 patients according to Gradation of Ascites

\begin{tabular}{|l|l|l|l|}
\hline Sr.no & $\begin{array}{l}\text { Gradation of } \\
\text { Ascites }\end{array}$ & $\begin{array}{l}\text { No. of } \\
\text { patient }\end{array}$ & Percentage \\
\hline 1 & Mild & 1 & $3.33 \%$ \\
\hline 2 & Moderate & 8 & $26.66 \%$ \\
\hline 3 & Gross & 21 & $70 \%$ \\
\hline
\end{tabular}

Gradation of ascites is done on basis of sonological findings as well as clinical examination, such as Fluid thrill, Shifting dull note, Horse-shoe shape dullness, and Puddle sign for mild ascites. These are the gradation parameters, to decide severity of fluid levels in abdomen.

\section{Statistical analysis}

In this clinical research study the clinical trial was conducted on 30 patients of Udara-Jatodakawastha with tablet Shardul Ghanavati. The statistical analysis was carried out by applying students paired t test and percentage of improvement was calculated by the formula.

\section{(Total B.T. - Total A.T.) $\times 100$}

Total B. T.

\section{Results}

Table no 4: Showing Effect of Shardula ghanavati on various parameters of Udara-Jatodakawastha in sitting position.

\begin{tabular}{|c|c|c|c|c|c|c|c|c|}
\hline \multirow{2}{*}{$\begin{array}{l}\text { Parameter } \\
(n=30)\end{array}$} & \multicolumn{2}{|c|}{ Mean score } & \multirow{2}{*}{$\begin{array}{l}\text { Mean } \\
\text { diff. }\end{array}$} & \multirow{2}{*}{$\begin{array}{l}\% \\
\text { change }\end{array}$} & \multirow[t]{2}{*}{ SD } & \multirow[t]{2}{*}{ SEM } & \multirow[t]{2}{*}{$\mathbf{t}$} & \multirow[t]{2}{*}{$\mathbf{P}$} \\
\hline & BT & AT & & & & & & \\
\hline Abdominal Girth & 97.73 & 86.03 & 11.7 & $11.98 \downarrow$ & 5.6453 & 1.030 & 11.35 & $<0.05$ \\
\hline $\begin{array}{l}\text { Distance between } \\
\text { Umbilicus - xiphi- } \\
\text { sternum }\end{array}$ & 23.43 & 17.6 & 5.83 & $24.89 \downarrow$ & 3.108 & 0.5674 & 10.27 & $<0.05$ \\
\hline $\begin{array}{l}\text { Distance between } \\
\text { Umbilicus -pubis }\end{array}$ & 14.93 & 11.03 & 3.9 & $26.12 \downarrow$ & 2.4718 & 0.4512 & 7.89 & $<0.05$ \\
\hline $\begin{array}{l}\text { Distance between } \\
\text { Umbilicus - RAS } \\
\text { iliac crest }\end{array}$ & 26.40 & 19.96 & 6.44 & $24.39 \downarrow$ & 3.5156 & 0.6418 & 10.29 & $<0.05$ \\
\hline $\begin{array}{l}\text { Distance between } \\
\text { Umbilicus - LAS } \\
\text { iliac crest }\end{array}$ & 26.3 & 20.03 & 6.27 & $23.84 \downarrow$ & 3.4828 & 0.6358 & 9.84 & $<0.05$ \\
\hline
\end{tabular}


Table no 5: Effect of Shardula ghanavati on various parameters of Udara-Jatodakawastha in supine position.

\begin{tabular}{|c|c|c|c|c|c|c|c|c|}
\hline Parameter & Mean & $\overline{\text { ore }}$ & Mean & & SD & SEM & $\mathbf{t}$ & $\overline{\mathbf{P}}$ \\
\hline$(n=30)$ & BT & AT & & & & & & \\
\hline Abdominal Girth & 92 & 81.56 & 10.44 & $11.34 \downarrow$ & 5.6453 & 1.030 & 9.66 & $<0.05$ \\
\hline $\begin{array}{l}\text { Distance between Umbilicus - } \\
\text { xiphisternum }\end{array}$ & 21.76 & 16.63 & 5.13 & $23.57 \downarrow$ & 2.7495 & 0.5019 & 10.22 & $<0.05$ \\
\hline $\begin{array}{l}\text { Distance between Umbilicus - } \\
\text { pubis }\end{array}$ & 15.13 & 10.66 & 4.47 & $29.54 \downarrow$ & 2.7748 & 0.5066 & 8.80 & $<0.05$ \\
\hline $\begin{array}{l}\text { Distance between Umbilicus - } \\
\text { RAS iliac crest }\end{array}$ & 24.43 & 19.1 & 5.33 & $21.81 \downarrow$ & 3.5156 & 0.6418 & 8.30 & $<0.05$ \\
\hline $\begin{array}{l}\text { Distance between Umbilicus - } \\
\text { LAS iliac crest }\end{array}$ & 24.56 & 18.8 & 5.76 & $23.45 \downarrow$ & 3.4828 & 0.6358 & 9.72 & $<0.05$ \\
\hline
\end{tabular}

(RAS-Right anterior superior, LAS- Left anterior superior, Dist.- Distance, bet.-between Diff.-Difference.)

Table No.6: Effect of Shardula ghanavati on various parameters of Udara-Jatodakawastha.

\begin{tabular}{|c|c|c|c|c|c|c|c|c|}
\hline Parameter & Mean & & Mean diff. & & SD & SEM & $\mathbf{t}$ & $\mathbf{P}$ \\
\hline$(n=30)$ & BT & AT & & change & & & & \\
\hline Weight & 61.43 & 53.76 & 7.67 & $12.48 \downarrow$ & 4.036 & 0.7368 & 10.39 & $<0.05$ \\
\hline $\begin{array}{l}\text { Gradation of } \\
\text { Ascites }\end{array}$ & 2.66 & 1.16 & 1.5 & $56.39 \downarrow$ & 0.5722 & 0.1044 & 14.36 & $<0.05$ \\
\hline $\begin{array}{l}\text { Gradation of } \\
\text { Agni }\end{array}$ & 2.56 & 1.06 & 1.5 & $58.59 \downarrow$ & 0.6822 & 0.1245 & 12.04 & $<0.05$ \\
\hline $\begin{array}{l}\text { Gradation of } \\
\text { Breathlessness }\end{array}$ & 3.4 & 1.3 & 2.1 & $61.76 \downarrow$ & 0.7588 & 0.1385 & 15.16 & $<0.05$ \\
\hline $\begin{array}{l}\text { Gradation of } \\
\text { Pedal edema }\end{array}$ & 3.16 & 1.23 & 1.93 & $61.07 \downarrow$ & 0.6913 & 0.1262 & 15.29 & $<0.05$ \\
\hline
\end{tabular}

n: number of patients; BT: before treatment; AT: after treatment; $\downarrow$ : decrease;

SD: standard deviation; SEM: standard error; $\mathrm{P}<0.05$ : $95 \%$ significant.

Table No.7: Effect of Shardul Ghanavati on mean score gradation status of various parameter of Udara Jatodakawastha, such as Breathlessness, Jatharagni, Amount of fluid, pedal edema etc. before and after treatment.

\begin{tabular}{|l|l|l|l|l|l|l|l|l|}
\hline Parameter & \multicolumn{2}{l|}{$\begin{array}{l}\text { Amount of } \\
\text { Fluid }\end{array}$} & \multicolumn{2}{l|}{ Agni } & \multicolumn{2}{l|}{ Breathless-ness } & \multicolumn{2}{l|}{ Pedal edema } \\
\cline { 2 - 9 } & BT & AT & BT & AT & BT & AT & BT & AT \\
\hline $\begin{array}{l}\text { Mean score } \\
\text { Gradation }\end{array}$ & 2.66 & 1.16 & 2.56 & 1.06 & 3.4 & 1.3 & 3.16 & 1.23 \\
\hline
\end{tabular}

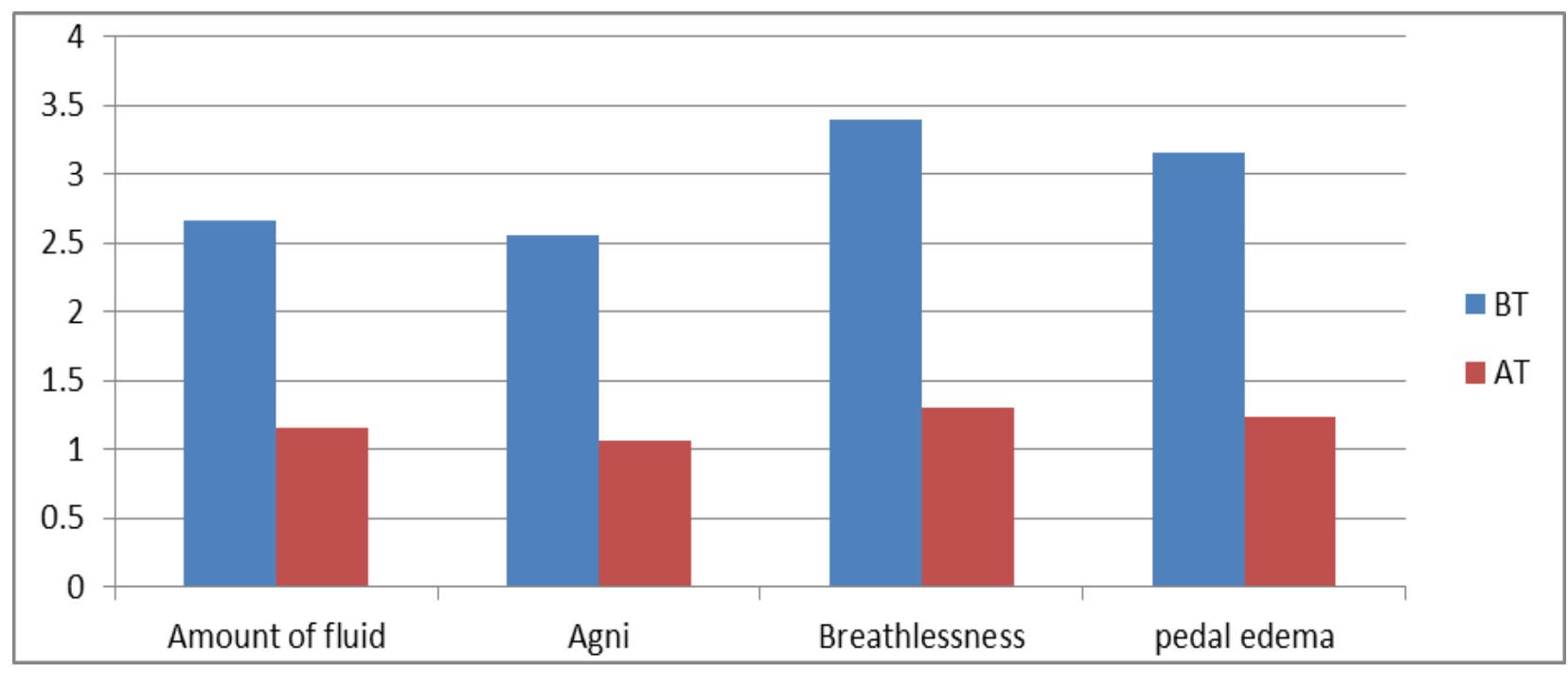


ISSN: 0976-5921

Sudarshan R Mehta et.al., Sudy of the efficacy of Shardul ghanvati in the management of Udara-Jatodakawastha

Table No.8: Effect of Shardul Ghanavati on abdominal girth of 30 patients of Udara-Jatodakawastha in sitting position.

\begin{tabular}{|l|l|l|l|l|l|l|}
\hline $\begin{array}{l}\text { Para- } \\
\text { meter }\end{array}$ & $\begin{array}{l}\mathbf{( n}= \\
\mathbf{3 0})\end{array}$ & $\begin{array}{l}\text { Abdominal } \\
\text { Girth } \\
\mathbf{( c m})\end{array}$ & $\begin{array}{l}\text { Dist. bet. Umbili- } \\
\text { cus - xiphister- } \\
\text { num } \\
\text { (cm) }\end{array}$ & $\begin{array}{l}\text { Dist. bet. Um- } \\
\text { bilicus - pubis } \\
\text { (cm) }\end{array}$ & $\begin{array}{l}\text { Dist. bet. Um- } \\
\text { bilicus - RAS } \\
\text { iliac crest (cm) }\end{array}$ & $\begin{array}{l}\text { Dist. bet. } \\
\text { Umbilicus - } \\
\text { LAS iliac } \\
\text { crest (cm) }\end{array}$ \\
\hline $\begin{array}{l}\text { Mean } \\
\text { Score }\end{array}$ & BT & 97.73 & 23.43 & 14.93 & 26.40 & 26.3 \\
\cline { 2 - 7 } & AT & 86.03 & 17.6 & 11.03 & 19.96 & 20.03 \\
\hline
\end{tabular}

Table No .9: Effect of Shardul Ghanavati on abdominal girth of 30 patients of Udara-Jatodakawastha in supine position.

\begin{tabular}{|l|l|l|l|l|l|l|}
\hline Parameter & $\mathbf{( n = 3 0 )}$ & $\begin{array}{l}\text { Abdominal } \\
\text { Girth (cm) }\end{array}$ & $\begin{array}{l}\text { Dist. bet. Umbil- } \\
\text { icus - xiphister- } \\
\text { num } \\
\text { (cm) }\end{array}$ & $\begin{array}{l}\text { Dist. bet. } \\
\text { Umbilics - } \\
\text { pubis } \\
\text { (cm) }\end{array}$ & $\begin{array}{l}\text { Dist. bet. Um- } \\
\text { bilics - RAS } \\
\text { iliac crest } \\
\text { (cm) }\end{array}$ & $\begin{array}{l}\text { Dist. bet. } \\
\text { Umbilics - } \\
\text { LAS iliac } \\
\text { crest (cm) }\end{array}$ \\
\hline $\begin{array}{l}\text { Mean } \\
\text { Score }\end{array}$ & BT & 92 & 21.76 & 15.13 & 24.43 & 24.56 \\
\cline { 2 - 7 } & AT & 81.56 & 16.63 & 10.66 & 19.1 & 18.8 \\
\hline
\end{tabular}

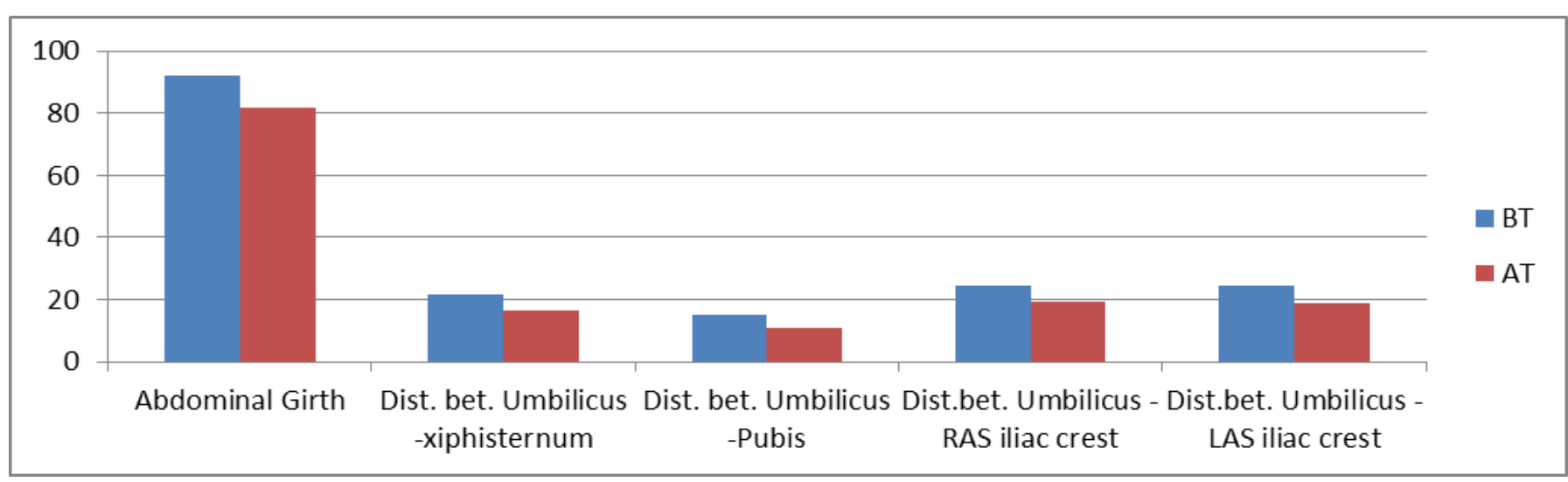

Table No. 10: Distribution of 30 patients according to percentage reduction in abdominal girth of 30 patients of Udara-Jatodakawastha.

\begin{tabular}{|l|l|l|l|}
\hline $\begin{array}{l}\text { Sr. } \\
\text { no }\end{array}$ & $\begin{array}{l}\text { Total percentage } \\
\text { reduction in } \\
\text { abdominal girth }\end{array}$ & $\begin{array}{l}\text { No. of } \\
\text { patients }\end{array}$ & Percentage \\
\hline 1 & $>15 \%$ & 23 & $76.66 \%$ \\
\hline 2 & $11 \%-15 \%$ & 05 & $16.66 \%$ \\
\hline 3 & $6 \%-10 \%$ & 00 & $00 \%$ \\
\hline 4 & $1 \%-5 \%$ & 01 & $3.33 \%$ \\
\hline 5 & No change & 01 & $3.33 \%$ \\
\hline
\end{tabular}

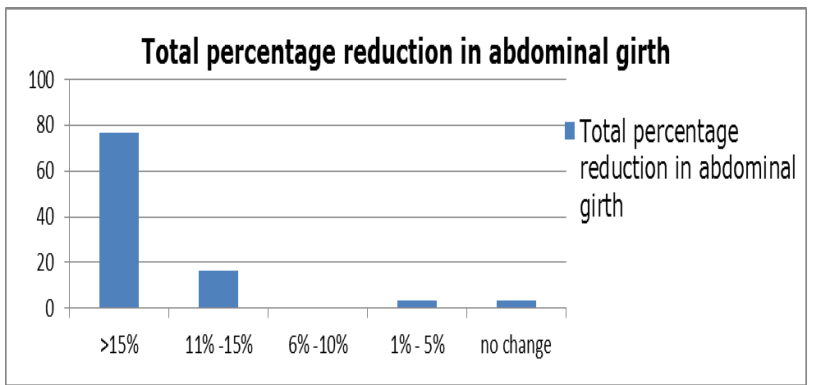

Above table shows that $76.66 \%$ patients have, $>15 \%$ total percentage reduction in abdominal girth while $16.66 \%$ patient shows total percentage reduction in abdominal girth in between $11 \%-15 \%$. Also above table shows each $3.33 \%$ patients have total reduction in abdominal girth in between $1 \%-5 \%$ and no change in abdominal girth respectively.

Table No. 11: Effect of Shardul Ghanavati on Weight of 30 patients of Udara-Jatodakawastha .

\begin{tabular}{|l|l|l|}
\hline Parameter & $(\mathbf{n}=\mathbf{3 0})$ & Weight $\mathbf{( k g )}$ \\
\hline $\begin{array}{l}\text { Mean } \\
\text { Score }\end{array}$ & BT & 61.43 \\
\cline { 2 - 3 } & AT & 53.76 \\
\hline
\end{tabular}

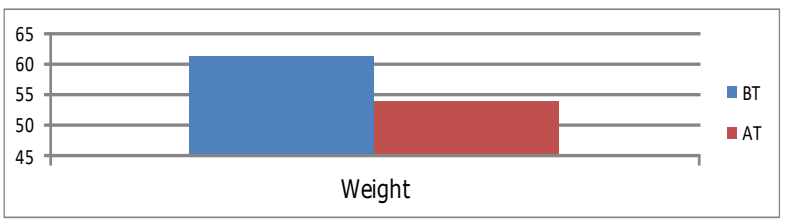

Mean score of reduction in weight of 30 patients of Udara - Jatodakawsatha was take place from $61.43 \mathrm{~kg}$ to $53.76 \mathrm{~kg}$, In duration of two months.i.e. $7.67 \mathrm{~kg}$ reduction in weight. That is in terms of percentage $12.48 \%$ reduction in weight take place. 
Above clinical research study in 30 patients of Udarajatodakawastha with tablet Shardul Ghanavati shows following results,

- The mean score of reduction in weight of 30 patients of Udara - Jatodakawsatha was take place from $61.43 \mathrm{~kg}$ to $53.76 \mathrm{~kg}$, in duration of two months.i.e. $7.67 \mathrm{~kg}$ reduction in weight. That is in terms of percentage $12.48 \%$ reduction in weight take place, which was statistically highly significant.

- Abdominal girth in sitting position was reduced by $11.97 \%$ whereas in supine position it was reduced by $11.34 \%$.Both these parameter shows highly significant results.

- Among the various distance measured, distance between Umbilicus and Xiphisternum was reduced by $29.15 \%$ and $23.57 \%$ in sitting and supine position respectively.

- Likewise, the distance between Umbilicus and Pubis was reduced by $26.12 \%$ and $29.54 \%$ in sitting and supine position respectively.

- The distance between Umbilicus to Right anterior superior iliac crest was reduced by $24.39 \%$ and $21.81 \%$ in sitting and supine position respectively.

- The distance between Umbilicus to Left anterior superior iliac crest was reduced by $23.84 \%$ and $23.45 \%$ in sitting and supine position respectively.

- Average change in gradation status that is, improvement in status of grades of amount of fluid in abdomen is take place from grade 2.66 to 1.16 and in terms of percentage average improvement in status of amount of fluidis $56.25 \%$.

- Average change in gradation status that is, improvement in status of agni is take place from grade 2.56 to 1.06 and in terms of percentage average improvement in status of agni is $58.44 \%$.

- Average change in gradation status that is, improvement in status of grades of Breathlessness is take place from grade 3.4 to 1.3 and in terms of percentage average improvement in status of Breathlessness is $61.76 \%$.

- average change in gradation status that is, improvement in status of grades of pedal edema is take place from grade 3.16 to 1.23 and in terms of percentage average improvement in status of pedal edema is $61.05 \%$.

- The efficacy of Ghanavati was proved by applying paired ' $\mathrm{t}$ ' test which give promising results. The total efficacy of treatment was $\mathbf{5 9 . 3 7 \%}$ in subjective criteria, and significant result found in objective criteria (weight \& girth measurement), as well as supplementary criteria.

- All these parameters has shown statistically highly significant results.

\section{Discussion}

In this study 30 patients were registered $\&$ have completed their full course of treatment.
Effect of therapy

Effect of Shardul Ghanavati on mean score gradation status of various parameter of Udara Jatodakawastha, such as Breathlessness, Jatharagni, Amount of fluid, pedal edema etc. before and after treatment.

- Average change in gradation status that is, improvement in status of grades of amount of fluid in abdomen is take place from grade 2.66 to 1.16 and in terms of percentage average improvement in status of amount of fluidis $56.25 \%$.

- Average change in gradation status that is, improvement in status of agni is take place from grade 2.56 to 1.06 and in terms of percentage average improvement in status of agni is $58.44 \%$.

- Average change in gradation status that is, improvement in status of grades of Breathlessness is take place from grade 3.4 to 1.3 and in terms of percentage average improvement in status of Breathlessnessis $61.76 \%$.

- average change in gradation status that is, improvement in status of grades of pedal edema is take place from grade 3.16 to 1.23 and in terms of percentage average improvement in status of pedal edema is 61.05 .

Effect of Shardul Ghanavati on abdominal girth of 30 patients of Udara- Jatodakawastha in sitting position.

Histogram 5.6 shows that,

- Abdominal girth is change from $97.73 \mathrm{~cm}$ to 86.03 $\mathrm{cm}$ i.e. $11.7 \mathrm{~cm}$ reduction in abdominal girth, In terms of percentage $11.97 \%$ reduction in abdominal girth.

- Mean score reduction of distance from umbilicus to xiphisternum is from $23.43 \mathrm{~cm}$ to $17.6 \mathrm{~cm}$ i.e. 6.83 $\mathrm{cm}$ reduction. In terms of percentage $29.15 \%$ reduction.

- Mean score reduction of distance from Umbilicus to pubis is from $14.93 \mathrm{~cm}$ to $11.03 \mathrm{~cm}$ i.e. $3.9 \mathrm{~cm}$ reduction. In terms of percentage $26.12 \%$ reduction.

- Mean score reduction of distance from Umbilicus to RAS iliac crest is from $26.40 \mathrm{~cm}$ to $19.96 \mathrm{~cm}$ i.e. $6.44 \mathrm{~cm}$ reduction. In terms of percentage $24.39 \%$ reduction.

- Mean score reduction of distance from Umbilicus to LAS iliac crest is from $26.30 \mathrm{~cm}$ to $20.03 \mathrm{~cm}$ i.e. $6.27 \mathrm{~cm}$ reduction. In terms of percentage $23.84 \%$ reduction

Effect of Shardul Ghanavati on abdominal girth of 30 patients of Udara- Jatodakawastha in supine position.

Histogram 5.7 shows that,

- Abdominal girth in supine position is change from $92 \mathrm{~cm}$ to $81.56 \mathrm{~cm}$ i.e. $10.44 \mathrm{~cm}$ reduction in abdominal girth, In terms of percentage $11.34 \%$ reduction in abdominal girth.

- Mean score reduction of distance from umbilicus to xiphisternum is from $21.76 \mathrm{~cm}$ to $16.63 \mathrm{~cm}$ i.e. 5.13 $\mathrm{cm}$ reduction. In terms of percentage $23.57 \%$ reduction.

- Mean score reduction of distance from Umbilicus to 
pubis is from $15.13 \mathrm{~cm}$ to $10.66 \mathrm{~cm}$ i.e. $4.47 \mathrm{~cm}$ reduction. In terms of percentage $29.54 \%$ reduction.

- Mean score reduction of distance from Umbilicus to RAS iliac crest is from $24.43 \mathrm{~cm}$ to $19.1 \mathrm{~cm}$ i.e. 5.33 $\mathrm{cm}$ reduction. In terms of percentage $21.81 \%$ reduction.

- Mean score reduction of distance from Umbilicus to LAS iliac crest is from $24.56 \mathrm{~cm}$ to $18.8 \mathrm{~cm}$ i.e. 5.76 $\mathrm{cm}$ reduction. In terms of percentage $23.45 \%$ reduction.

\section{Percentage reduction in abdominal girth of $\mathbf{3 0}$} patients of Udara-Jatodakawastha.

- Histogram 5.8 Shows that, that $76.66 \%$ patients shows $>15 \%$ total percentage reduction in abdominal girth while $16.66 \%$ patient shows total percentage reduction in abdominal girth in between $11 \%-15 \%$. Also above table shows each $3.33 \%$ patients have total reduction in abdominal girth in between $1 \%$ $5 \%$ and no change in abdominal girth respectively.

\section{Effect of Shardul Ghanavati on Weight of 30 patients of Udara-Jatodakawastha.}

- Histogram 5.9 shows that, the mean score of reduction in weight of 30 patients of Udara Jatodakawsatha was take place from $61.43 \mathrm{~kg}$ to $53.76 \mathrm{~kg}$, in duration of two months.i.e.7.67 kg reduction in weight. That is in terms of percentage $12.48 \%$ reduction in weight take place.

\section{Total effect of therapy}

The total efficacy of treatment was $\mathbf{5 9 . 3 7 \%}$ in subjective criteria, and significant result found in objective criteria (weight \& girth measurement), as well as supplementary criteria.

Though the subject Udara roga and its management is vast to study, on ayurvedic aetiological factors, diagnosis and treatment, here attempt is made by doing clinical (experimental) research work and literature study of Udara roga.

Udara-Jatodakawastha (Ascites) is mostly found in middle and old age, the incidence of disease is higher in male patients with mixed diet. Most of the patients were primary educated or illiterate. The observation reveals that the majority of patients were service man \& small scale business holders. In the majority of patients the prime cause of disease is Alcohol intake (80\%) for prolong duration.

The majority of patients have dietary habit vishamashana, status of agni- Manda, Koshtakrura,most of patient come to hospital when they have gross ascites.

\section{Probable mode of action of Shardul Ghanavati in treating Udara-jatodakawstha:}

The reference of this kalpa is from Ashtanghridaya chikitsasthana, Gulma chikitsa adhaya 14/36. It is given in the form of churna, but considering the quantity and acceptance of the drug I have used it in Ghanavati form in my project work. Ingredient of Ghanavati are as follows.

\begin{tabular}{|c|c|c|c|c|c|c|}
\hline Sr. No & Plant name & Rasa & Vipaka & Veerya & Guna & Karma(5) \\
\hline 1 & Hingu & Katu & Katu & Ushna & $\begin{array}{l}\text { Laghu, } \\
\text { Snigdha } \\
\text { Tikshna }\end{array}$ & $\begin{array}{l}\text { Deepan, pachan, Shulahar, Ruchya } \\
\text { Shwasahar }\end{array}$ \\
\hline 2 & Vacha & $\begin{array}{l}\text { Tikta, } \\
\text { Katu }\end{array}$ & Katu & Ushna & $\begin{array}{l}\text { Laghu, } \\
\text { Tikshna }\end{array}$ & Agnideepan, Pachan, Lekhaniya \\
\hline 3 & Bidlawan & Lawan & - & Ushna & $\begin{array}{l}\text { Tikshna, } \\
\text { Vikasi }\end{array}$ & Adhmanahar, Deepan, Udarashulhar \\
\hline 4 & Shunthi & Katu & Madhura & Ushna & $\begin{array}{l}\text { Laghu, } \\
\text { snigdha }\end{array}$ & $\begin{array}{l}\text { Agnideepan, Aamapachana, } \\
\text { Shothahar. }\end{array}$ \\
\hline 5 & Ajagi(jirak) & Katu & Katu & Ushna & $\begin{array}{l}\text { Laghu, } \\
\text { Snigdha } \\
\text { Tikshna }\end{array}$ & $\begin{array}{l}\text { Ruchya, Deepya, Agnivardhaka, } \\
\text { Pachana, Balya }\end{array}$ \\
\hline 6 & Haritaki & $\begin{array}{l}\text { Kashya } \\
\text { rasa } \\
\text { pradhan, } \\
\text { pancha- } \\
\text { rasatmak }\end{array}$ & Madhur & Ushna & $\begin{array}{l}\text { Laghu, } \\
\text { Ruksha }\end{array}$ & $\begin{array}{l}\text { Tridoshhar, Deepan, Pachan, } \\
\text { Anuloman }\end{array}$ \\
\hline 7 & Pushkarmul & $\begin{array}{l}\text { Tikta, } \\
\text { Katu }\end{array}$ & Katu & Ushna & Laghu & $\begin{array}{l}\text { Agnideepan, Aamapachana, } \\
\text { Jalashoshak, Parshwashulhar }\end{array}$ \\
\hline 8 & Kushtha & $\begin{array}{l}\text { Tikta, } \\
\text { Katu } \\
\text { Madhur }\end{array}$ & Katu & Ushna & $\begin{array}{l}\text { Laghu, } \\
\text { Raghu, } \\
\text { Tikshna }\end{array}$ & Hikka, shwasa, Kasahar, Lekhaniya. \\
\hline 9 & Nishotar & $\begin{array}{l}\text { Tikta, } \\
\text { Katu } \\
\text { Madhur }\end{array}$ & Katu & Ushna & $\begin{array}{l}\text { Laghu, } \\
\text { Raghu, } \\
\text { Tikshna }\end{array}$ & $\begin{array}{l}\text { Sukhavirechaka, Bhedaniya, } \\
\text { Krumihara }\end{array}$ \\
\hline 10 & Danti & Katu & Katu & Ushna & $\begin{array}{l}\text { Guru } \\
\text { Tikshna }\end{array}$ & Tikkshnavirechak, Swedajana, \\
\hline
\end{tabular}


Due to Agnimandya and Aama sanchya there is formation of abnormal Rasa dhatu so that, obstruction of srotasa takes place .Due to Aamsanchaya \& srotorodha there is increase in dosha sanchaya \& Prana,Agi \& Aapan are gaited vitiated, Srotorodha especially take place

In Udaka \& Swedavaha srotas. And then by Upsnehana nyaya (6) fluid get accumulate in Audarya kala and leads to asites. In this way srotorodha is main reason for Udara roga.

\section{Rational behind the selection of drug}

The formulation Shardul Ghanavati is selected for the study has described in Ashtanghirdaya Samhita Chikitsasthan 14/36, in the management of UdaraJatodakawastha as it contains Hingu, Vacha, Bidlawan, Shunthi, Jirak, Haritaki, Kushtha, Pushkarmul, Nishotar and Danti in an increasing order.

Among the above selected drugs Dantimul root is strongly Virechak and mutral, drug Nishotar and Haitaki are virechaka and anulomaka, pushkarmul is shoshak and rest all drugs are Agnideepak, pachak and adhmanvibandhar. And all above is appropriate treatment of this disease, Hence the drug Shardul Ghanavati has been proven very useful in UdaraJatodakawastha.

According to Harrison (7) patients of small amounts of ascites can usually be managed with dietary sodium restriction alone. When a moderate amount of ascites present, diuretic therapy is usually necessary .If ascites is still present, with high doses of diuretics in patients who are compliant with a low sodium diet, then they are defined as having refractory ascites, and alternative treatment modalities including repeated large volume paracentesis, or a TIPS (Transjugular Intrahepatic Porto - Systemic Shunt) procedure should be considered. Recent studies have shown that, TIPS while managing the ascites, does not improve survival of patients. Unfortunately, TIPS is often associated with an increased frequency of hepatic encephalopathy. The prognosis for patients of cirrhosis with ascites is poor and some studies have shown that $<50 \%$ of patients survive 2 years after the onset of ascites. So, there should be consideration for liver transplantation in patients with the onset of ascites (8).Thus, to avoid repeated paracentesis and also transplantation, it was planned to use the Ayurvedic medicine for such disease. Also prevalence of patients coming to our hospital was considerably high, also this disease was one of the leading cause of death in present society, so I desirably decided \& worked over it.

Abdominal paracentesis is conducted in those patients who have gross ascites and having respiratory distress. These patients after paracentesis choose for clinical research study, i.e. total 3 pateint out of total 30. Their weight and abdominal girth measurements are taken after paracentesis, and the present treatment procedure is considerd as initial measurement for starting tablet Shardul Ghanvati.Few patients having gross ascites and respiratory distress along with complication such as HRS Type 1 \& HRS Type 2, Hepatic encephalopathy, Portal hypertension with bleeding were not included in this study.

\section{Conclusion}

The formulation shardul ghanavati was found an excellent remedy for Udara-Jatodakawastha. The tablet Shardul Ghanavati shows promising results on all parameters of assessment criteria of disease. i.e. on Weight, Abdominal Girth in sitting and standing position. On Gradation of amount of fluid, Breathlessness, Status of Agni,\& gradation of pedal edema.

The tablet Shardul Ghanavati is clinically safe \& effective herbal preparation having no any side effects.In management of Udara-Jatodakawastha (Ascites) along with proper pathya \& Dugdh-Aahar this drug have valuable answer.

\section{References}

1. Http:// www.ncbi.nlm.nih.gov.> article

2. "Agnivesh Charak samhita" Elaborated by Charak \& Redacted by Drudhabal Edited with Hindi commentary "Vaidyamanorama" by Acharya Vidyadhar Shukla \& Professor Ravi Dutt Tripathi, Volume 02 foreword by Acharya Priy Vrata Sharma Chaukhamba Sanskrit Pratishthan Delhi.Sanskaran 2007.Charak chikitsasthan 13/12.page no 301.

3. "Sarth Vagbhata" Elaborated by Dr. Ganesh Krushna Garde, Introduction by Prof. Subhash Ranade \& Dr. Shri. Vidya. Published by Anamol Prakashana, Pune 02.Publisher Mr.Mo.D.Nandurkar Reprint May 2008. Ashtanghirdaya chikitsashan $14 / 36$ page no 294.

4. Research methodology \& Medical statistics -Patil \& Kanap Chaukhamba surbharti prakashan edition 2015.

5. Dravyaguna Vidnyana A. P. Jawalgekar \& Dr. Deshpande Anmol Prakashana, Pune $4^{\text {th }}$ Edition, 1996.

6. The Chaukhamba Ayuvijnan Granthamala Sushruta Samhita of Maharshi Susruta volume 1.Edited with "Susrutavimarsini" Hindi commentary by Dr. Anant Ram Sharma, Forworded by Acharya Priyavat Sharma. Chaukhamba Surbharati Prakashan Varanasi Reprint 2006.Shusrut.sam.Nidansthan. Udarnidanam 7/5,6 page no.510

7. Harrison's principle of internal medicine $17^{\text {th }}$ edition pg.no 1192.

8. Davidson's Principles and Practice of Medicine, Sir. Stanley Davidson. Churchill Livingstone, Harcourt Publishers Ltd $21^{\text {ST }}$ Edition, 2010.Page no.921, 936 \& 938. 